\title{
Non-psychogenic polydipsia in 45-year-old man with primary hyperparathyroidism and recurrent bilateral nephrolithiasis
}

\author{
Rahmat Cahyanur, ${ }^{1}$ Johannes Sarwono, ${ }^{2}$ Linda Armelia, ${ }^{2}$ Maruhum B.H. Marbun, ${ }^{2}$ Pradana Soewondo ${ }^{3}$ \\ ${ }^{1}$ Department of Internal Medicine, Faculty of Medicine, Universitas Indonesia, Jakarta, Indonesia \\ ${ }^{2}$ Division of Nephrology, Department of Internal Medicine, Faculty of Medicine, Universitas Indonesia - Cipto Mangunkusumo General \\ Hospital, Jakarta, Indonesia \\ ${ }^{3}$ Division of Endocrinology, Department of Internal Medicine, Faculty of Medicine, Universitas Indonesia - Cipto Mangunkusumo \\ General Hospital, Jakarta, Indonesia
}

\begin{abstract}
Abstrak
Polidipsia non psikogenik dengan hiponatremia adalah kondisi klinis yang jarang ditemukan. Hiperparatiroidisme primer merupakan kelainan kalsium, fosfat, serta metabolism tulang akibat kelebihan hormon paratiroid. Angka insiden kejadian hiperparatiroidisme adalah 21,6 dari 100.000 orang setiap tahunnya. Artikel ini melaporkan seorang pasien laki-laki 45 tahun dengan polidipsia non psikogenik. Pasien ini meminum air yang banyak untuk menghindari batu ginjal berulang. Pasien tersebut memiliki riwayat batu ginjal berulang disertai dengan hiperkalsemia. Evaluasi lebih lanjut penyebab hiperkalsemia pada kasus tersebut disebabkan oleh hiperparatiroidisme primer. (Med J Indones. 2012;21:230-4)
\end{abstract}

\begin{abstract}
Non-psychogenic polydipsia with hyponatremia is a rare clinical presentation. Primary hyperparathyroidism is a disorder of calcium, phosphate, and bone metabolism caused by increased level of parathyroid hormone (PTH). It is estimated the incidence of primary hyperparathyroidism are 21.6 per 100,000 person a year. This case report describe a 45 -yearold man presented with non-psychogenic polydipsia. This patient drank a lot of water out of the fear of recurrent kidney stones. He had history of recurrent nephrolithiasis with hypercalcemia. We investigate further the cause of hypercalcemia and we diagnosed primary hyperparathryoidism as the cause. (Med J Indones. 2012;21:230-4)
\end{abstract}

Keywords: Hyponatremia, non-psychogenic polydipsia, primary hyperparathyroidism

Non-psychogenic polydipsia (individuals without identifiable psychiatric, brain, or endocrine disorder) with hyponatremia is a rare clinical presentation. Hyponatremia occurs due to excessive water intake which overwhelms renal excretory capacity. ${ }^{1}$

Primary hyperparathyroidism is a disorder of calcium, phosphate, and bone metabolism caused by increased level of parathyroid hormone (PTH). ${ }^{2}$ It is estimated the incidence of primary hyperparathyroidism are 21.6 per 100,000 person a year. ${ }^{3}$ Approximately 15 $20 \%$ patients with primary hyperparathyroidism had nephrolithiasis. Other manifestations of renal involvement in primary hyperparathyroidism were hypercalciuria, nephrocalcinosis, and chronic renal insufficiency. ${ }^{4}$

This case report describes a 45-year-old man with symptoms of severe hyponatremia due to iatrogenic polydipsia. This patient also had recurrent bilateral nephrolithiasis with mild hypercalcemia that lead us into primary hyperparathyroidism. This case report gives us lesson in evaluating recurrent nephrolithiasis patient and also remind us the importance of patient education, especially in correcting wrong perception of popular belief.

\section{CASE ILLUSTRATION}

A man, 45 years old, came to our out patient clinic with a chief complain of malaise and weakness since one month before. His other complaints include nausea, loss of appetite and headache. He had been taking a daily consumption of 8 liters of water for two months prior to admission, with the amount of urine up to 10 liters. He drank a lot of water out of the fear of recurrent kidney stones.

The patient had a history of bilateral flank pain that started 15 years ago. He noted a passing stone, red or cloudy urination episodes for several time. He had seen a doctor for this problem and was diagnosed with stones in both kidneys. A surgical removal of the stone was suggested, but the patient refused to undergo the operation due to financial limitation. Instead, he took pain killer and herbal medication to relieve pain.

Three years ago, the patient felt the worst flank pain he ever experienced. He consented to a right kidney opensurgery to remove the stone. He felt improvement in his condition, and there was reduced numbers of flank pain attacks. 
Six months ago, he started to experience bilateral flank pain again, along with intermittent episode of redcolored urine and pain during urination. He decided to go to Jakarta and was admitted at our hospital. Some investigations had been carried out, including plain abdominal $\mathrm{X}$ rays, kidney ultrasound, and abdominal CT scan. Plain abdominal $\mathrm{X}$ rays showed stag horn stone in the left kidney and multiple stones in the right kidney. Kidney ultrasound revealed normal sized kidney with multiple hyper-echoic with acoustic shadow in both kidneys, without signs of urinary tract obstruction (Figure 1A). Abdominal CT scan showed bilateral nephrocalcinosis and left nephrolithiasis (Figure 1B).
He finally proceeded with percutaneous stone removal for his left kidney, followed by bilateral shock-wave litothotripsy (Figure 2). The stone analysis showed that $83 \%$ of stone consisted of calcium oxalate and the rest was brusit.

On initial evaluation, the patient was fully alert although looking weak. He had an increased blood pressure $(170 / 90 \mathrm{mmHg})$, pulse rate $(96 \mathrm{x} /$ minute), respiratory rate $(20 \mathrm{x} /$ minute $)$, but there was no fever. Physical examination revealed a surgical scar in his right flank. There weren't any palpable mass or tenderness.

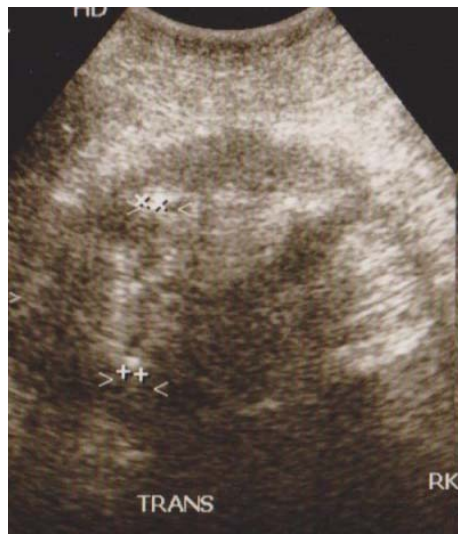

(A)

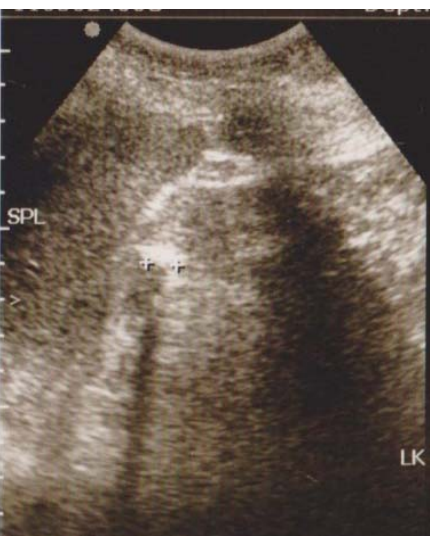

LK

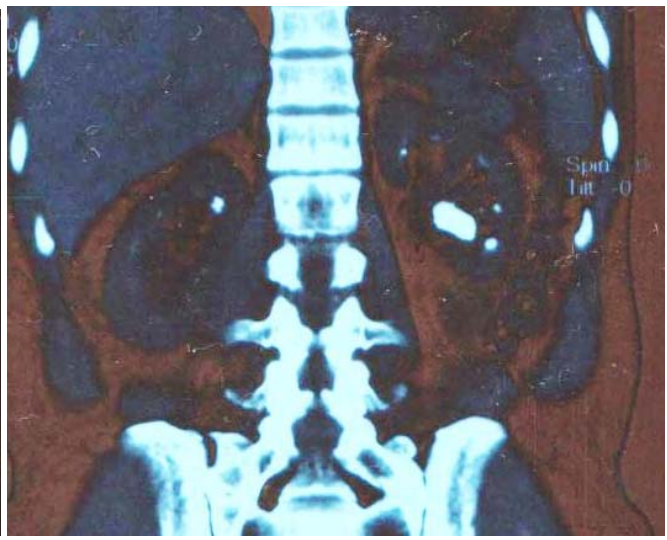

(B)

Figure 1. (A) Abdominal ultrasound revealed multiple hyper-echoic lesion with acoustic shadows. (B) Abdominal CT scan showed bilateral nephrocalcinosis and left kidney stones
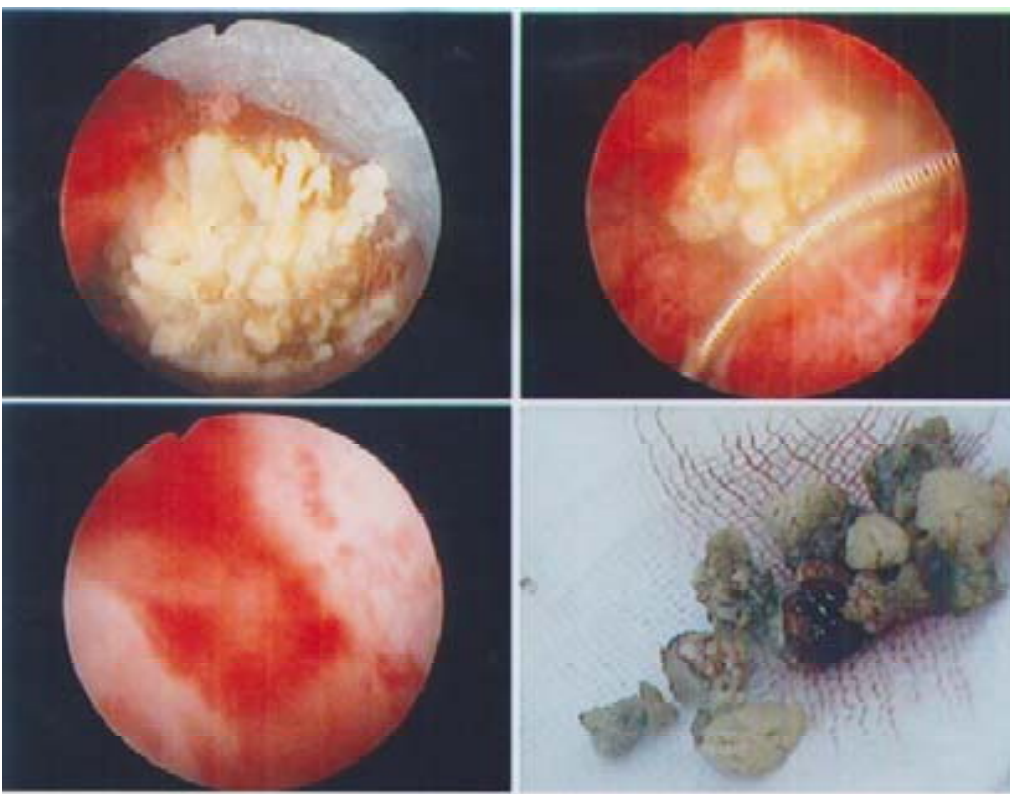

Figure 2. Kidney stones after percutaneous stones removal 
Laboratory findings demonstrated very low sodium, plasma osmolality, and potassium concentration, low phosphate concentration, and elevations of serum creatinin, calcium, and uric acid levels. His kidney function was also decreased, as shown by low creatinin clearance. Urine examination revealed 12 liter of urine volume, with low urine osmolarity and increased level of calcium in the $24 \mathrm{~h}$ urine. There were not any marked abnormalities in the peripheral blood count and blood gas analysis. The laboratory findings are presented in table 1 .

Based on those findings, the patient was diagnosed with hyponatremia due to iatrogenic polydipsia, chronic kidney disease, mild hypercalcemia, uncontrolled hypertension, recurrent bilateral nephrolithiasis, hyperuricemia, and hypokalemia.

The patient was then advised on a gradual fluid restriction to $2 \mathrm{~L} /$ day, high potassium diet, normal calcium intake $(>1000 \mathrm{mg})$, low purine, and dietary protein restriction $(0,8 \mathrm{~g} / \mathrm{bw} / \mathrm{d})$. Medications given were valsartan $160 \mathrm{mg}$ od, amlodipine $5 \mathrm{mg}$ od, potassium citrate tid, folic acid $15 \mathrm{mg}$ od, thiamine tid, and allopurinol $100 \mathrm{mg}$ od.

Since laboratory findings had shown mild hypercalcemia and low serum phosphate, a PTH intact assay was ordered to evaluate the possibility of primary hyperparathyroidism. During follow-up, the patient claimed to feel better, fluid intake had been reduced into $2 \mathrm{~L}$ /day with approximately same urine volume. Patient's blood pressure was controlled. Laboratory findings returned to normal values. The patient was also educated to restrict sodium intake (100 meq/day).

During follow-up, the PTH intact assay was 189.40 $\mathrm{pg} / \mathrm{ml}$ (normal range: $15-65 \mathrm{pg} / \mathrm{ml}$ ). The parathyroid ultrasound was ordered, but it could not detect any abnormalities in the neck. The patient was further advised to perform sestamibi scan for localizing abnormal gland. Unfortunately, he refused the possibility of surgically removing his parathyroid gland. He refused further work-ups and discharged from hospital.

\section{DISCUSSION}

The patient presented with malaise and weakness due to severe hyponatremia and hypokalemia. Further work-up for hyponatremia revealed low plasma and urine osmolarity. This finding corresponds to primary polydipsia. The patient had a history of consuming water up to 8 liters in a day. This action was caused by misunderstanding about the prevention of kidney stone, which is based on the popular belief that drinking plenty of water would prevent the stone formation. The management of primary polydipsia is to reduce the water intake. After the advice of gradual decrease of fluid intake into $2 \mathrm{~L}$ a day, the patient felt an improvement of his condition. The sodium level also returned to normal. The patient was then educated on the actual prevention of kidney stone formation, which is that the fluid intake should be adjusted until the urine production reaches $2 \mathrm{~L} /$ day. Previous publication also reported a similar case of severe hyponatremia in non-psychogenic elderly female due to water-drinking. ${ }^{1}$

All patients with kidney stone should undergo further evaluation to find risk factors for stone formation, urinalysis, and stone analysis. The results of serum electrolyte levels and a chemistry panel may help identify certain disorders, such as primary hyperparathyroidism. ${ }^{5}$ The patient described in this case had recurrent bilateral nephrolithiasis and nephrocalcinosis, which leads a

Table 1. Laboratory parameter of blood plasma and urine analysis

\begin{tabular}{llllll}
\hline Parameter & Result & Normal value & Parameter & Result & Normal value \\
\hline Sodium & $118 \mathrm{meq} / \mathrm{L}$ & $132-147$ & Plasma osmolarity & $200 \mathrm{mOsm} / \mathrm{kg}$ & $275-295$ \\
Potassium & $2.59 \mathrm{meq} / \mathrm{L}$ & $3.30-5.40$ & Urine osmolarity & $99 \mathrm{mOsm} / \mathrm{kg}$ & $400-800$ \\
Chloride & $86.4 \mathrm{meq} / \mathrm{L}$ & $94.0-111.0$ & Urine sodium & $214 \mathrm{meq} / 24 \mathrm{~h}$ & $30-220$ \\
Ureum & $44 \mathrm{mg} / \mathrm{dL}$ & $<50$ & Urine potassium & $44 \mathrm{meq} / 24 \mathrm{~h}$ & $25-100$ \\
Creatinin & $2.3 \mathrm{mg} / \mathrm{dL}$ & $0.8-1.3$ & Urine chloride & $202 \mathrm{meq} / 24 \mathrm{~h}$ & $94-110$ \\
Uric acid & $10.2 \mathrm{mg} / \mathrm{dL}$ & $<7$ & Urine volume & $12600 \mathrm{~L} / 24 \mathrm{~h}$ & \\
Albumin & $4 \mathrm{~g} / \mathrm{dL}$ & $3.4-4.8$ & Urine calcium & $315 \mathrm{mg} / 24 \mathrm{~h}$ & $100-320$ \\
Globulin & $3.2 \mathrm{~g} / \mathrm{dL}$ & $1.8-3.9$ & Urine uric acid & $655.2 \mathrm{mg} / 24 \mathrm{~h}$ & $20-1000$ \\
Calcium & $11.2 \mathrm{mg} / \mathrm{dL}$ & $8.4-10.2$ & Creatinin clearance & $38.17 \mathrm{mg} / \mathrm{kg} / 24 \mathrm{~h}$ & \\
Phosphate & $2.2 \mathrm{mg} / \mathrm{dL}$ & $2.7-4.5$ & Alkaline phosphatase & $99 \mathrm{U} / \mathrm{L}$ & $<128$ \\
\hline
\end{tabular}


suspicion of metabolic derangements. Stone analysis found calcium stone, which is commonly associated with a number of metabolic derangements. ${ }^{6}$ Results of serum electrolyte revealed mild hypercalcemia, hypophosphatemia, and hypercalciuria. Based on those findings, a serum PTH was ordered to evaluate hypercalcemia. In this case, an increased level of PTH was established. Hypercalcemia with increased PTH level generally supports the diagnosis of primary hyperparathyroidism. ${ }^{7}$ Serum calcium level in patient with primary hyperparathyroidism is often modestly increased, usually between $10-11.5 \mathrm{mg} / \mathrm{dL} .^{6}$ It is estimated that $5 \%$ of patient with nephrolithiasis was caused by primary hyperparathyroidism. ${ }^{4}$ Elevated parathyroid hormone level would stimulate calcium reabsorption in the distal tubules, decrease phosphate reabsorption, and increase $1 \alpha$-hydroxylase. In the bone, parathyroid hormone would accelerate bone turnover and release calcium into circulation. ${ }^{8}$ Hypercalciuria in primary hyperparathyroidism is caused by the increase of filtered calcium due to hypercalcemia. Hypercalciuria is associated with stone formation, which is found in $35-40 \%$ patients with primary hyperparathyroidism. ${ }^{4}$

Primary hyperparathyroidism is most often caused by a single adenoma (80-85\%) and gland hyperplasia (10$15 \%)$. It may occur as a single abnormality, but may also be a part of hereditary syndrome, such as Multiple Endocrine Neoplasia. ${ }^{7}$ The next step performed was identifying abnormal parathyroid tissue. In this case, a parathyroid ultrasound was conducted, but it didn't reveal any abnormalities. Ultrasound is a non-invasive method to visualize abnormal parathyroid gland. It has a sensitivity of $42-82 \%$ and specificity of $90 \%$. Other imaging modalities that can be performed are sestamibi scan, neck and mediastinum CT scan, or arteriography. Further imaging evaluation was not conducted due to the patient's disconsent of surgical treatment. No abnormalities were detected in imaging evaluation. However, the diagnosis of primary hyperparathyroidism is based on biochemical findings and is not affected by the result of imaging studies. ${ }^{9}$

This patient's clinical condition was an indication for surgical removal of parathyroid gland. This patient had recurrent bilateral calcium oxalate stone, nephrocalcinosis, and low creatinin clearance level. Since this patient refused to have the surgery, only conservative treatment was given. In this case, the patient was advised to take an adequate fluid intake with urine volume of $2 \mathrm{~L} /$ day, normal calcium intake (> $1000 \mathrm{mg})$, restricted sodium intake $(100 \mathrm{meq} /$ day), dietary protein restriction $(0,8 \mathrm{gram} / \mathrm{bw} / \mathrm{d})$, and allopurinol to prevent recurrent stone formation. Low calcium intake should be avoided since it would increase urinary oxalate excretion, in comparison to normal calcium intake. Limited sodium diet would enhance proximal sodium and calcium reabsorption, which reduce calcium excretion. Dietary protein restriction, especially of animal protein (high sulphurcontaining amino acids), can reduce the daily acid load in the kidney. Allopurinol therapy also reduces stone recurrence, because it is suggested that reduced uric acid secretion would prevent stone formation..$^{10}$ Another option for surgical approach is minimal invasive parathyroidectomy. This technique gives similar results compared with open surgery. The requirements for this technique are unequivocal imaging suggesting unilateral pathology, no suggestion of concomitant, thyroid disease requiring surgical intervention, and no family history of multiple endocrine neoplasia. ${ }^{11}$ In this case based on the ultrasound we did not manage to locate abnormal parathyroid gland.

Until now, there is no definitive medical therapy for symptomatic primary hyperparathyroidism. In cases of low bone densitometry, antiresorptive therapy could be given. Bisphosphonate could increase bone mineral density, but not significantly reduce the serum calcium or PTH level. Meanwhile, for patients with normal bone densitometry, calcimimetic agent could normalize serum calcium level and slightly reduce PTH level. Levels of 25-hydroxyvitamin D should be measured. In primary hyperparathyroidism, the level of 25-hydroxyvitamin D is expectedly low, probably because of its increased conversion to 1,25 dihydroxyvitamin D. This condition may further aggravate PTH secretion. ${ }^{7}$ Unfortunately, the patient didn't consent to further examinations such as bone densitometry or 25 -hydroxyvitamin $\mathrm{D}$ level.

In conclusion, excessive water intake meant to be preventive measurement of stone formation leads to severehyponatremiadue tonon-psychogenic polydipsia. This situation remind us of the importance of patient education. Recurrent bilateral nephrolithiasis in this case arrouse the suspicion of metabolic abnormalities. Concurrent hypercalcemia, hypophosphatemia, hypercalciuria, and nephrocalcinosis suggested abnormal PTH secretion. Increased PTH level in this case confirmed primary hyperparathyroidism. Further evaluation did not manage to locate abnormal parathyroid gland. Unfortunately, this patient left the possibility for further work-up, since he refused the idea of surgical treatment.

\section{REFERENCES}

1. Weiss GJ. Non-psychogenic polydipsia with hyponatremia. Int J Nephrol. 2005;2(1). 
2. Potts JT. Diseases of parathyroid gland and other hyperand hypocalcemic disorders. In: Fauci AS, Braunwald E, Kasper DL, Hauser SL, Longo DL, Jameson JL, Loscalzo J, editors. 17th ed. New York: McGraw Hills; 2008. p. 2377-96.

3. Wermers R, Khosla S, Atkinson E, Achenbach S, Oberg A, Grant $\mathrm{C}$, et al. Incidence of primary hyperparathyroidism in Rochester, Minnesota, 1993-2001: an update on the changing epidemiology of the disease. J Bone Miner Res. 2006;21:171-7.

4. Fuleihan GE-H, Silverberg SJ. Clinical manifestations of prymary hyperparathyroidism [Internet]. 2009. Available from: http://www.uptodate.com/contents/clinicalmanifestations-of-primary-hyperparathyroidism.

5. Preminger GM, Curhan GC. The first kidney stone and asymptomatic nephrolithiasis in adults [Internet]. 2009. Available from: http://www.uptodate.com/contents/the-firstkidney-stone-and-asymptomatic-nephrolithiasis-in-adults.
6. Worcester EM, Coe FL. Nephrolithiasis. Prim Care. 2008;35:369-91.

7. Marcocci C, Cetani F. Clinical practice. Primary hyperparathyroidism. N Engl J Med. 2011;365:2389-97.

8. Parathyroid gland \& calcium \& phosphate regulation. In: Molina PE, editor. Endocrine physiology. New York: McGraw Hills; 2010.

9. Bilezikian JP. Primary hyperparathyroidism. New York [cited 2011 Dec 26]; Available from: http://www.endotext. org/parathyroid/parathyroid5/parathyroidframe5 $\mathrm{htm}$.

10. Curhan GC. Prevention of recurrent calcium stones in adults [Internet]. 2009. Available from: http://www.uptodate.com/ contents/prevention-of-recurrent-calcium-stones-in-adults.

11. Perrier ND, Dickson PV. Parathyroid exploration for primary hyperparathyroidism [Internet]. 2011. Available from: http:// www.uptodate.com/contents/parathyroid-exploration-forprimary-hyperparathyroidism. 